\title{
Self-reference in Research Articles aCross EUROPE ANd ASIA: A Review OF STUdies
}

\begin{abstract}
Numerous cross-linguistic and cross-disciplinary studies have looked at the manifestation of author stance in academic texts. One of the most recurrent areas of contrast has been the use of personal pronouns across linguistic and disciplinary cultures. This paper aims at reviewing previous research on self-reference in research articles taking an intercultural perspective. It focuses on 22 studies which report on results regarding this stance feature in 13 lingua-cultural contexts (Bulgarian, Chinese, Danish, Dutch, English, French, German, Italian, Lithuanian, Norwegian, Persian, Russian, Spanish). They have been extracted from relevant publications in the fields of English for Academic Purposes and English for Specific Purposes over the past 25 years (1998-2012). A close analysis of this research highlights different cultural trends in constructing writer-reader relationships in this academic genre and reveals important methodological issues across different studies. This review article also has implications for English as a lingua franca (cf. Mauranen 2012) as used in international publications.
\end{abstract}

\section{Keywords}

Academic discourse; research article; self-reference; cross-linguistic research; identity; personal pronouns

\section{Introduction}

English is, no doubt, the language of science and knowledge communication and scientists and academics from different linguistic and cultural background (to a varying extent across different disciplines and areas of knowledge) are increasingly pressed to publish the results of their research in English-medium publications. By so doing, their research gains further visibility - their potential readership being 
widened -, they are more likely to gain greater recognition, and their research be better assessed by different national and international associations for quality assurance in higher education. Such spread in the use of English for Research Publication Purposes (Cargill and Burgess 2008) has brought about a considerable number of studies in the field of English for Academic Purposes (EAP), looking at the contrastive use of linguistic, discursive and rhetorical features in different academic genres carried out by academics across different language and cultural backgrounds. As a result, for the past decade terms like national identity, disciplinary identity, author identity have become buzz words in the EAP field.

Most of these studies attempt to define specific academic discourse features of their respective cultural communities taking Anglophone academic discourse as the basis for comparison. A major conclusion from such studies is that these features not only show specific cultural patterns that prevail in a particular language, but also help to trace some trends that are typical of a particular discipline irrespective of culture, simultaneously highlighting differences in epistemological traditions of different disciplines (see, for example, Fløttum et al. 2006; Lafuente-Millán et al. 2010).

The majority of previous intercultural studies of academic discourse focus on written genres. These studies are framed within Contrastive Rhetoric, defined as "an area of research in second language acquisition that identifies problems in composition encountered by second language writers and, by referring to the rhetorical strategies of the first language, attempts to explain them" (Connor 1996: 5). Despite receiving criticism for being reductionist and for its ethnocentricity, empowering the Anglo-American tradition in its early stages (Kaplan 1966, 1988), contrastive studies of different academic genres in two languages have been prolific in EAP and have informed EAP instruction and materials. A changing notion of culture, however, from a rather received view to a more "non-standard" view has led to the postulation of Intercultural Rhetoric (Connor 2004a, 2004b). A more complex view of culture was deemed necessary, according to which an individual can simultaneously be a member of several small cultures (e.g. professional, academic, disciplinary, etc.) and big (e.g. national) cultures, the former with their particular norms, values and conventions overlapping with the latter (Atkinson 2004). Intercultural Rhetoric is, therefore, put forward to better account for the changes Contrastive Rhetoric has undergone since its outset:

The term intercultural rhetoric better describes the broadening trends of writing across languages and cultures. It preserves the traditional approaches that use text analysis, genre analysis, and corpus analysis as well introduces [sic] the ethnographic approaches that examine language in interactions. Furthermore, it connotes the analysis of texts that allows for dynamic definitions of culture and the inclusion of smaller cultures (e.g. disciplinary, classroom) in the analysis. (Connor 2004a: 273)

Even though various academic genres have been interculturally analysed, not limiting the research to professional writers, but also looking into the features of 
learner academic language, the research article (RA) has attracted most scholarly attention in EAP in general and in cross-cultural studies within it in particular. This is hardly surprising, as "research papers are still the main means by which the majority of academics disseminate their work and establish their reputations" (Hyland 2005a: 89).

The amount of intercultural empirical studies on various aspects of a RA is considerable, ranging from investigations of lexis and grammatical constructions (e.g. Mur-Dueñas 2010; Diani 2008; Murillo 2012; Vold 2006, inter alia) to structural, argumentational and rhetorical analysis of text features (e.g. Loi and Evans 2010; Martín-Martín and Burgess 2004; Sala 2008; Sheldon 2011, inter alia).

One of the areas of EAP enjoying much scholarly attention is that of metadiscourse. Even though many frameworks of metadiscourse have been put forward (cf. Ädel 2006; Crismore et al. 1993; Dahl 2004; Markkanen et al. 1993; Mauranen 1993; Vande Kopple 1985, 2002), Hyland's metadiscourse model (2005a) and his stance and engagement model (2005b) have been particularly popular in EAP studies. Both models deal with various linguistic resources that help authors of scientific texts to achieve different rhetorical and pragmatic goals: to organize discourse, to engage the reader into the argumentation, to show varying degrees of commitment to their propositions, etc. Both frameworks list self-reference as one of the important features of academic rhetoric because, as Hyland (2005b: 181) puts it, "[p]resenting a discoursal self is central to the writing process".

Indeed, the projection of the author's visibility in the text through self-mentions, that is, authorial personal reference, has been of great EAP scholarly interest. This interest may have been generated by the fact that the expression of author identity is clearly culture specific. Another reason may be diverging recommendations and guidelines regarding the use of self-mentions in academic English textbooks and resources (see Hyland 2002; Bennett 2009), which has led researchers to investigate the actual use of this means of self-representation in academic texts in different languages based on comparable, usually small size corpora compiled for this special research purpose.

Self-reference is a particularly important rhetorical trait since it contributes to manifesting author stance in the texts and to projecting a positive image, which can affect the authors' persuasiveness in their argumentation and presentation of research results. It can, therefore, allow academics to portray themselves as expert, reliable members of a given disciplinary community (Hyland 2001, 2002). Alternatively, personal pronouns can help mitigate the proposition they modify, especially in combinations with mental state predicates, which create the effect of the speaker "voicing a tentative and personal opinion which may be wrong" (Nuyts 2001: 391).

The aim of this article is to review previous studies of how self-reference is used in RAs published in different languages and cultures to see to what extent any general conclusions could be drawn regarding the author stance academics from different language and cultural backgrounds tend to take when they publish their research results. Most research has taken a comparative perspective looking 
at self-reference patterns in RAs in English and a number of different L1s in a wide array of disciplines, as will be discussed in the following sections of the paper. The review of those research studies will allow us to determine the extent to which the degree of self-representation in the academic genre of the RAs is shown to be subject to change across different languages and cultures. Moreover, some research has also been undertaken on the use of self-reference in RAs in English written by academics from different lingua-cultural backgrounds. The review of this research will help determine to what extent when using English for international communication scholars from different backgrounds make a similar or different use of this interactional feature to that made in their L1s and/or by researchers from other language cultural backgrounds. Reviewing such studies will enable us to check the validity of the (lack of) discursive hybridity (Mauranen et al. 2010) in the use of English as a lingua franca in the academia, as stemming from existing literature.

\section{Studies reviewed}

As self-reference is a widely researched EAP aspect investigated in different modes and genres, we decided to focus the review only on research dealing with cross-linguistic studies and only on the RA genre (i.e. we did not take into consideration numerous literature on self-reference in cross-disciplinary studies in English only, in abstracts or other academic genres, including learner language). With this focus in mind, we searched relevant publications in the leading journals in applied linguistics as well as in edited volumes covering the span of 25 years, i.e. from 1998 to $2012 .{ }^{1}$ A total of 22 articles were found which included in their research aims / data on the use of personal pronouns in RAs written in different languages and/or contexts of publication. In our review we included both studies that focused exclusively on personal pronouns and studies where the analysis of personal pronouns was part of a wider study. We then carefully studied and grouped them under different lingua-cultural background of the RA authors on which the research was based.

In order to group the research articles under review, we used the United Nations geoscheme (http://unstats.un.org/unsd/methods/m49/m49regin.htm) for the following geographical divisions: (i) Southern Europe (Spanish and Italian), (ii) Western Europe (Dutch, French, German), Eastern Europe (Bulgarian and Russian) and Northern Europe (Danish, Lithuanian and Norwegian), (iii) Southern and Eastern Asia (Persian and Chinese). We are aware of the fact that the geographical division may not accurately reflect the rhetorical peculiarities of discourses of different languages, yet a certain established pattern was needed to group the studies under review. Therefore, the geographical division, which may be considered rather neutral, has been chosen as the basis for grouping the studies reviewed. 
The material that was used for the review is summarized in Table 1:

Table 1. An overview of the studies reviewed focusing on self-references in RA writing taking an intercultural perspective.

\begin{tabular}{|c|c|c|c|c|}
\hline $\begin{array}{l}\text { Lingua-cultural } \\
\text { background }\end{array}$ & $\begin{array}{c}\text { Studies } \\
\text { analyzed }\end{array}$ & $\begin{array}{c}\text { Scope } \\
\text { of the study }\end{array}$ & $\begin{array}{c}\text { Corpus } \\
\text { size }\end{array}$ & $\begin{array}{c}\text { Corpus design } \\
\text { features }\end{array}$ \\
\hline \multicolumn{5}{|c|}{ Southern Europe } \\
\hline \multirow[t]{5}{*}{ Spanish (8) } & $\begin{array}{l}\text { Martínez } \\
\text { (2005) }\end{array}$ & $\begin{array}{l}\text { RA Methods sec- } \\
\text { tions in Biology } \\
\text { L1 vs L2 English }\end{array}$ & $\begin{array}{l}1 \text { million words } \\
\text { published RAs } \\
15 \text { manuscripts in } \\
\text { Spanish }\end{array}$ & $\begin{array}{l}\text { RAs in English } \\
\text { speaking countries } \\
\text { vs RAs written by } \\
\text { Argentinian authors } \\
\text { in English }\end{array}$ \\
\hline & $\begin{array}{l}\text { Mur-Due- } \\
\text { ñas (2007) }\end{array}$ & $\begin{array}{l}\text { RAs in Business } \\
\text { Management } \\
\text { L1 English vs L1 } \\
\text { Spanish }\end{array}$ & $\begin{array}{l}12 \text { RAs in English } \\
12 \text { RAs in Spanish } \\
\text { (140,000 words) }\end{array}$ & $\begin{array}{l}\text { Single and co- } \\
\text { authored RAs in } \\
\text { English by authors } \\
\text { affiliated at North } \\
\text { American institutions } \\
\text { published in interna- } \\
\text { tional sites vs Span- } \\
\text { ish RAs by Spanish } \\
\text { authors published in } \\
\text { national sites }\end{array}$ \\
\hline & $\begin{array}{l}\text { Carciu } \\
(2009)\end{array}$ & $\begin{array}{l}\text { RAs in Biomedi- } \\
\text { cine } \\
\text { L1 vs L2 English }\end{array}$ & $\begin{array}{l}24 \text { RAs in English } \\
24 \text { RAs in Spanish } \\
\text { English } \\
(164,000 \text { words })\end{array}$ & $\begin{array}{l}\text { English RAs by } \\
\text { native speakers } \\
\text { (English or Spanish) } \\
\text { as judged per their } \\
\text { names and affiliation. } \\
\text { RAs published in in- } \\
\text { ternational journals. }\end{array}$ \\
\hline & $\begin{array}{l}\text { Sheldon } \\
\text { (2009) }\end{array}$ & $\begin{array}{l}\text { RAs in Applied } \\
\text { Linguistics and } \\
\text { Language Teaching } \\
\text { L1 English vs L1 } \\
\text { Spanish }\end{array}$ & $\begin{array}{l}18 \text { RAs in English } \\
18 \text { RAs in Spanish } \\
\text { (252,000 words) }\end{array}$ & $\begin{array}{l}\text { English RAs ad- } \\
\text { dressed to an inter- } \\
\text { national readership } \\
\text { vs. Castilian Spanish } \\
\text { RAs addressed to } \\
\text { a national reader- } \\
\text { ship. First language } \\
\text { determined based on } \\
\text { surnames and home } \\
\text { institutions. }\end{array}$ \\
\hline & $\begin{array}{l}\text { Pérez-Llan- } \\
\text { tada (2010) }\end{array}$ & $\begin{array}{l}\text { RA Introductions } \\
\text { and Discussions in } \\
\text { Biomedicine } \\
\text { L1 English vs L2 } \\
\text { English vs L1 } \\
\text { Spanish }\end{array}$ & $\begin{array}{l}24 \text { RAs in English } \\
24 \text { RAs in Spanish } \\
24 \text { RAs in Spanish } \\
\text { English (205,283 } \\
\text { words) }\end{array}$ & $\begin{array}{l}\text { English RAs written } \\
\text { by North American } \\
\text { based scholars pub- } \\
\text { lished in international } \\
\text { journals. Spanish and } \\
\text { Spanish English RAs } \\
\text { by Castilian authors } \\
\text { published in national } \\
\text { and international } \\
\text { journals respectively. }\end{array}$ \\
\hline
\end{tabular}




\begin{tabular}{|c|c|c|c|c|}
\hline $\begin{array}{l}\text { Lingua-cultural } \\
\text { background }\end{array}$ & $\begin{array}{c}\text { Studies } \\
\text { analyzed }\end{array}$ & $\begin{array}{c}\text { Scope } \\
\text { of the study }\end{array}$ & $\begin{array}{c}\begin{array}{c}\text { Corpus } \\
\text { size }\end{array} \\
\end{array}$ & $\begin{array}{c}\begin{array}{c}\text { Corpus design } \\
\text { features }\end{array} \\
\end{array}$ \\
\hline & $\begin{array}{l}\text { Williams } \\
(2010)\end{array}$ & $\begin{array}{l}\text { RA Methods in } \\
\text { Biomedicine } \\
\text { L1 English vs L1 } \\
\text { Spanish vs. English } \\
\text { to Spanish transla- } \\
\text { tions }\end{array}$ & $\begin{array}{l}\text { 64 English source } \\
\text { language (SL) texts } \\
\text { (41,850 words); } \\
64 \text { Spanish target } \\
\text { language (TL) texts } \\
\text { (49,570 words); } \\
64 \text { comparable } \\
\text { Spanish native lan- } \\
\text { guage (NL) texts } \\
(30,265 \text { words) }\end{array}$ & $\begin{array}{l}\text { English RAs pub- } \\
\text { lished in Anglo- } \\
\text { American journals vs } \\
\text { Spanish translations } \\
\text { and Spanish compa- } \\
\text { rable texts. }\end{array}$ \\
\hline & $\begin{array}{l}\text { Lorés-Sanz } \\
\text { (2011a) }\end{array}$ & $\begin{array}{l}\text { RAs in Business } \\
\text { Management } \\
\text { L1 English vs L2 } \\
\text { English vs L1 } \\
\text { Spanish }\end{array}$ & $\begin{array}{l}18 \text { RAs in English } \\
\text { (146,030 words) } \\
18 \text { RAs in Spanish } \\
\text { (128,788 words) } \\
18 \text { RAs in Spanish } \\
\text { English (146,967 } \\
\text { words) }\end{array}$ & $\begin{array}{l}\text { Co-authored RAs } \\
\text { published in English } \\
\text { in international publi- } \\
\text { cations of high im- } \\
\text { pact by Anglophone } \\
\text { speakers, published } \\
\text { in English in interna- } \\
\text { tional publications by } \\
\text { Spanish writers and } \\
\text { published in Spanish } \\
\text { by Spanish writers in } \\
\text { national publications. }\end{array}$ \\
\hline & $\begin{array}{l}\text { Lorés-Sanz } \\
\text { (2011b) }\end{array}$ & $\begin{array}{l}\text { RAs in Business } \\
\text { Management } \\
\text { L1 English vs L2 } \\
\text { English vs L1 } \\
\text { Spanish }\end{array}$ & $\begin{array}{l}18 \text { RAs in English; } \\
18 \text { RAs in Spanish; } \\
18 \text { RAs in Spanish } \\
\text { English (414,872 } \\
\text { words) }\end{array}$ & $\begin{array}{l}\text { Co-authored RAs } \\
\text { published in English } \\
\text { in international publi- } \\
\text { cations of high im- } \\
\text { pact by Anglophone } \\
\text { speakers, published } \\
\text { in English in interna- } \\
\text { tional publications by } \\
\text { Spanish writers and } \\
\text { published in Spanish } \\
\text { by Spanish writers in } \\
\text { national publications. }\end{array}$ \\
\hline \multirow[t]{3}{*}{ Italian (2) } & $\begin{array}{l}\text { Bondi } \\
\text { (2007) }\end{array}$ & $\begin{array}{l}\text { RA openings in } \\
\text { History } \\
\text { L1 English vs L1 } \\
\text { Italian }\end{array}$ & $\begin{array}{l}280 \text { RA openings } \\
\text { in English }(95,682 \\
\text { words); } 310 \text { RA } \\
\text { openings in Italian } \\
(97,513 \text { words })\end{array}$ & $\begin{array}{l}\text { No attempt to } \\
\text { separate native from } \\
\text { non-native speakers/ } \\
\text { writers. }\end{array}$ \\
\hline & $\begin{array}{l}\text { Molino } \\
(2010)\end{array}$ & $\begin{array}{l}\text { RAs in Linguistics } \\
\text { L1 English vs L1 } \\
\text { Italian }\end{array}$ & $\begin{array}{l}30 \text { RAs in English } \\
(237,408 \text { words) } \\
30 \text { RAs in Italian } \\
\text { (202,984 words) }\end{array}$ & $\begin{array}{l}\text { Single authored texts } \\
\text { in English written } \\
\text { by scholars based in } \\
\text { Anglo-American } \\
\text { Universities vs. texts } \\
\text { in Italian written by } \\
\text { scholars based in } \\
\text { Italian Universities. }\end{array}$ \\
\hline & \multicolumn{4}{|c|}{ Eastern Europe } \\
\hline Bulgarian (2) & $\begin{array}{l}\text { Vassileva } \\
(1998)\end{array}$ & $\begin{array}{l}\text { RAs in Linguistics } \\
\text { L1 English vs L1 } \\
\text { Bulgarian }\end{array}$ & $\begin{array}{l}300 \text { pages for each } \\
\text { language }\end{array}$ & $\begin{array}{l}\text { Single authored } \\
\text { articles published } \\
\text { in leading journals } \\
\text { and collections of } \\
\text { articles, no specific } \\
\text { requirements for au- } \\
\text { thors indicated. }\end{array}$ \\
\hline
\end{tabular}




\begin{tabular}{|c|c|c|c|c|}
\hline $\begin{array}{l}\text { Lingua-cultural } \\
\text { background }\end{array}$ & $\begin{array}{c}\text { Studies } \\
\text { analyzed }\end{array}$ & $\begin{array}{c}\text { Scope } \\
\text { of the study }\end{array}$ & $\begin{array}{c}\begin{array}{c}\text { Corpus } \\
\text { size }\end{array} \\
\end{array}$ & $\begin{array}{c}\begin{array}{c}\text { Corpus design } \\
\text { features }\end{array} \\
\end{array}$ \\
\hline & $\begin{array}{l}\text { Shaw \& } \\
\text { Vassileva } \\
(2009)\end{array}$ & $\begin{array}{l}\text { RAs in Economics } \\
\text { L1 English vs L1 } \\
\text { Bulgarian }\end{array}$ & $\begin{array}{l}19 \text { RAs in Bulgar- } \\
\text { ian } \\
27 \text { RAs in English }\end{array}$ & $\begin{array}{l}\text { Specific selection of } \\
\text { articles from vari- } \\
\text { ous periods in time } \\
\text { from 1900. "The } \\
\text { authors of the articles } \\
\text { selected appeared to } \\
\text { be native speakers" } \\
\text { (2009: 294). }\end{array}$ \\
\hline Russian (1) & $\begin{array}{l}\text { Vassileva } \\
\text { (1998) }\end{array}$ & $\begin{array}{l}\text { RAs in Linguistics } \\
\text { L1 English vs L1 } \\
\text { Russian }\end{array}$ & $\begin{array}{l}300 \text { pages for each } \\
\text { language }\end{array}$ & $\begin{array}{l}\text { Single authored } \\
\text { articles published } \\
\text { in leading journals } \\
\text { and collections of } \\
\text { articles. No specific } \\
\text { requirements for au- } \\
\text { thors indicated. }\end{array}$ \\
\hline \multicolumn{5}{|c|}{ Northern Europe } \\
\hline \multirow[t]{2}{*}{ Danish (2) } & $\begin{array}{l}\text { Shaw } \\
(2003)\end{array}$ & $\begin{array}{l}\text { RA Introductions } \\
\text { in Applied Eco- } \\
\text { nomics } \\
\text { L1 English vs L2 } \\
\text { English vs L1 Dan- } \\
\text { ish }\end{array}$ & $\begin{array}{l}10 \text { RAs in Danish } \\
10 \text { RAs in English } \\
10 \text { RAs in Danish } \\
\text { English }\end{array}$ & $\begin{array}{l}\text { English authors } \\
\text { based in US, Britain } \\
\text { or New Zealand } \\
\text { institutions and "at } \\
\text { least one member of } \\
\text { each authorial } \\
\text { team has an Anglo- } \\
\text { Saxon name" (2003: } \\
\text { 347). }\end{array}$ \\
\hline & $\begin{array}{l}\text { Shaw \& } \\
\text { Vassileva } \\
\text { (2009) }\end{array}$ & $\begin{array}{l}\text { RAs in Economics } \\
\text { L1 English vs L1 } \\
\text { Danish }\end{array}$ & $\begin{array}{l}25 \text { RAs in Danish } \\
27 \text { RAs in English }\end{array}$ & $\begin{array}{l}\text { Specific selection of } \\
\text { articles from vari- } \\
\text { ous periods in time } \\
\text { from } 1900 \text { "The } \\
\text { authors of the articles } \\
\text { selected appeared to } \\
\text { be native speakers" } \\
\text { (2009: 294). }\end{array}$ \\
\hline Lithuanian (1) & $\begin{array}{l}\text { Šinkūnienè } \\
(2010)\end{array}$ & $\begin{array}{l}\text { RAs in Linguistics } \\
\text { and Medicine } \\
\text { L1 English vs L1 } \\
\text { Lithuanian }\end{array}$ & $\begin{array}{l}19 \text { RAs in Lithu- } \\
\text { anian Linguistics } \\
\text { ( } 74,500 \text { words); } \\
26 \text { RAs in Lithu- } \\
\text { anian Medicine } \\
\text { ( } 74,769 \text { words); } \\
13 \text { RAs in English } \\
\text { Linguistics ( } 75,229 \\
\text { words); } 20 \text { RAs in } \\
\text { English Medicine } \\
\text { ( } 75,049 \text { words) }\end{array}$ & $\begin{array}{l}\text { Single and multiple- } \\
\text { authored texts written } \\
\text { by American authors } \\
\text { (based on affiliation) } \\
\text { published in inter- } \\
\text { national journals } \\
\text { vs texts written by } \\
\text { Lithuanian authors } \\
\text { (based on affiliation) } \\
\text { published in local } \\
\text { journals. }\end{array}$ \\
\hline Norwegian (1) & $\begin{array}{l}\text { Fløttum et } \\
\text { al. (2006) }\end{array}$ & $\begin{array}{l}\text { RAs in Linguistics, } \\
\text { Economics and } \\
\text { Medicine } \\
\text { L1 English vs L1 } \\
\text { Norwegian }\end{array}$ & $\begin{array}{l}300 \text { RAs (50 in } \\
\text { each discipline and } \\
\text { language); English } \\
\text { subcorpus: } 899,780 \\
\text { words; Norwegian } \\
\text { subcorpus: } 685,423 \\
\text { words }\end{array}$ & $\begin{array}{l}\text { RAs controlled for } \\
\text { nationality, gender, } \\
\text { the number of au- } \\
\text { thors for each article; } \\
\text { some limitations of } \\
\text { balancing mentioned. }\end{array}$ \\
\hline
\end{tabular}




\begin{tabular}{|c|c|c|c|c|}
\hline $\begin{array}{l}\text { Lingua-cultural } \\
\text { background }\end{array}$ & $\begin{array}{c}\text { Studies } \\
\text { analyzed }\end{array}$ & $\begin{array}{c}\text { Scope } \\
\text { of the study }\end{array}$ & $\begin{array}{c}\text { Corpus } \\
\text { size }\end{array}$ & $\begin{array}{c}\text { Corpus design } \\
\text { features }\end{array}$ \\
\hline \multicolumn{5}{|c|}{ Western Europe } \\
\hline Dutch (1) & $\begin{array}{l}\text { Šinkūnienė } \\
\& \text { Van Ol- } \\
\text { men (2012) }\end{array}$ & $\begin{array}{l}\text { RAs in humanities } \\
\text { and social sciences } \\
\text { L1 English vs L1 } \\
\text { Dutch }\end{array}$ & $\begin{array}{l}\text { Dutch corpus: } 60 \\
\text { articles from hu- } \\
\text { manities, "similar } \\
\text { number" from } \\
\text { social sciences } \\
\text { ( } 898,603 \text { words). } \\
\text { English corpus: } \\
\text { the humanities and } \\
\text { social sciences } \\
\text { subcorpora of } \\
\text { COCA (19,859,431 } \\
\text { words) }\end{array}$ & $\begin{array}{l}\text { Articles written by } \\
\text { different authors } \\
\text { from } 2000 \text { until } \\
2012 \text {. No specific } \\
\text { requirements for } \\
\text { authors indicated. }\end{array}$ \\
\hline \multirow[t]{2}{*}{ French (2) } & $\begin{array}{l}\text { Vassileva } \\
\text { (1998) }\end{array}$ & $\begin{array}{l}\text { RAs in Linguistics } \\
\text { L1 English vs L1 } \\
\text { French }\end{array}$ & $\begin{array}{l}300 \text { pages for each } \\
\text { language }\end{array}$ & $\begin{array}{l}\text { Single authored } \\
\text { articles published } \\
\text { in leading journals } \\
\text { and collections of } \\
\text { articles, no specific } \\
\text { requirements for au- } \\
\text { thors indicated. }\end{array}$ \\
\hline & $\begin{array}{l}\text { Fløttum et } \\
\text { al. (2006) }\end{array}$ & $\begin{array}{l}\text { RAs in Linguistics, } \\
\text { Economics and } \\
\text { Medicine } \\
\text { L1 English vs L1 } \\
\text { French }\end{array}$ & $\begin{array}{l}300 \text { RAs (50 in } \\
\text { each discipline and } \\
\text { language); English } \\
\text { subcorpus: } 899,780 \\
\text { words; French } \\
\text { subcorpus: } 665,665 \\
\text { words }\end{array}$ & $\begin{array}{l}\text { RAs controlled for } \\
\text { nationality, gender, } \\
\text { the number of au- } \\
\text { thors for each article, } \\
\text { with some limitations } \\
\text { of balancing men- } \\
\text { tioned. }\end{array}$ \\
\hline \multirow[t]{3}{*}{ German (3) } & $\begin{array}{l}\text { Vassileva } \\
\text { (1998) }\end{array}$ & $\begin{array}{l}\text { RAs in Linguistics } \\
\text { L1 English vs L1 } \\
\text { German }\end{array}$ & $\begin{array}{l}300 \text { pages for each } \\
\text { language }\end{array}$ & $\begin{array}{l}\text { Single authored } \\
\text { articles published } \\
\text { in leading journals } \\
\text { and collections of } \\
\text { articles, no specific } \\
\text { requirements for au- } \\
\text { thors indicated. }\end{array}$ \\
\hline & $\begin{array}{l}\text { Sanderson } \\
(2008)\end{array}$ & $\begin{array}{l}\text { RAs in Philosophy, } \\
\text { History, Folklore, } \\
\text { Literary studies, } \\
\text { Linguistics } \\
\text { L1 English vs L1 } \\
\text { German }\end{array}$ & $\begin{array}{l}100 \text { RAs, } 50 \text { in } \\
\text { German, } 25 \text { in Brit- } \\
\text { ish English, } 25 \text { in } \\
\text { American English } \\
\text { (1 million words) }\end{array}$ & $\begin{array}{l}\text { RAs controlled for } \\
\text { native language of } \\
\text { the authors, gender, } \\
\text { age (six age groups) } \\
\text { and academic status } \\
\text { (four levels). Articles } \\
\text { published in leading } \\
\text { journals. }\end{array}$ \\
\hline & $\begin{array}{l}\text { Shaw \& } \\
\text { Vassileva } \\
\text { (2009) }\end{array}$ & $\begin{array}{l}\text { RAs in Economics } \\
\text { L1 English vs L1 } \\
\text { German }\end{array}$ & $\begin{array}{l}20 \text { RAs in German } \\
27 \text { RAs in English }\end{array}$ & $\begin{array}{l}\text { Specific selection of } \\
\text { articles from various } \\
\text { periods in time from } \\
1900 \text {."The authors of } \\
\text { the articles selected } \\
\text { appeared to be na- } \\
\text { tive speakers" (2009: } \\
\text { 294). }\end{array}$ \\
\hline
\end{tabular}




\begin{tabular}{|c|c|c|c|c|}
\hline $\begin{array}{l}\text { Lingua-cultural } \\
\text { background }\end{array}$ & $\begin{array}{c}\text { Studies } \\
\text { analyzed }\end{array}$ & $\begin{array}{c}\text { Scope } \\
\text { of the study }\end{array}$ & $\begin{array}{c}\text { Corpus } \\
\text { size }\end{array}$ & $\begin{array}{c}\text { Corpus design } \\
\text { features }\end{array}$ \\
\hline \multicolumn{5}{|c|}{ Southern Asia } \\
\hline \multirow[t]{4}{*}{ Persian (4) } & Abdi (2009) & $\begin{array}{l}\text { RAs in Sociology, } \\
\text { Education, Psy- } \\
\text { chology, Physics, } \\
\text { Chemistry, Medi- } \\
\text { cine } \\
\text { L1 English vs L1 } \\
\text { Persian }\end{array}$ & $\begin{array}{l}36 \text { RAs in Persian, } \\
36 \text { RAs in English } \\
\text { ( } 6 \text { articles from } \\
\text { each discipline and } \\
\text { language) }\end{array}$ & $\begin{array}{l}\text { At least one na- } \\
\text { tive speaker author } \\
\text { (judged by name and } \\
\text { affiliation). Persian } \\
\text { RAs from SID data- } \\
\text { base, English RAs } \\
\text { from sciencedirect. }\end{array}$ \\
\hline & $\begin{array}{l}\text { Zarei \& } \\
\text { Mansoori } \\
\text { (2011) }\end{array}$ & $\begin{array}{l}\text { RAs in Applied } \\
\text { Linguistics and } \\
\text { Computer Engi- } \\
\text { neering } \\
\text { L1 English vs L1 } \\
\text { Persian }\end{array}$ & $\begin{array}{l}9 \text { RAs in English } \\
\text { (50,602 words), } \\
10 \text { RAs in Persian } \\
\text { (51,691 words) }\end{array}$ & $\begin{array}{l}\text { RAs written in Eng- } \\
\text { lish by at least one } \\
\text { native speaker author } \\
\text { as judged by af- } \\
\text { filiation to US or UK } \\
\text { academic institutions } \\
\text { and a native speaker } \\
\text { of Persian for the } \\
\text { Persian RAs. Articles } \\
\text { selected from well- } \\
\text { known, refereed, } \\
\text { recently published } \\
\text { journals. }\end{array}$ \\
\hline & $\begin{array}{l}\text { Fatemi \& } \\
\text { Mirshojaee } \\
\text { (2012) }\end{array}$ & $\begin{array}{l}\text { RAs in Sociology } \\
\text { and Linguistics } \\
\text { L1 English vs L1 } \\
\text { Persian }\end{array}$ & $\begin{array}{l}20 \text { RAs in English, } \\
20 \text { RAs in Persian. } \\
\text { Every group of } 10 \\
\text { articles has } 437,00 \\
\text { words }\end{array}$ & $\begin{array}{l}\text { Native English and } \\
\text { Persian authors. RAs } \\
\text { selected from Iranian } \\
\text { and international } \\
\text { English journals. }\end{array}$ \\
\hline & $\begin{array}{l}\text { Taki \& } \\
\text { Jafarpour } \\
\text { (2012) }\end{array}$ & $\begin{array}{l}\text { RAs in Chemistry } \\
\text { and Sociology } \\
\text { L1 English vs L1 } \\
\text { Persian }\end{array}$ & $\begin{array}{l}30 \text { RAs from each } \\
\text { discipline and } \\
\text { language } \\
(423,332 \text { words })\end{array}$ & $\begin{array}{l}\text { Iranian journals for } \\
\text { Persian RAs and } \\
\text { international journals } \\
\text { for English RAs. }\end{array}$ \\
\hline \multicolumn{5}{|c|}{$\begin{array}{l}\text { Eastern Asia } \\
\end{array}$} \\
\hline Chinese (1) & $\begin{array}{l}\text { Dawang } \\
(2006)\end{array}$ & $\begin{array}{l}\text { RA results and dis- } \\
\text { cussion sections in } \\
\text { material sciences } \\
\text { L1 English vs L2 } \\
\text { English (for a lo- } \\
\text { cal audience) vs } \\
\text { L2 English (for an } \\
\text { international audi- } \\
\text { ence) }\end{array}$ & $\begin{array}{l}60 \text { RA parts: } 20 \\
\text { Chinese scholar } \\
\text { RAs in local } \\
\text { Chinese English } \\
\text { journals (16,442 } \\
\text { words); } \\
20 \text { Chinese scholar } \\
\text { RAs in internation- } \\
\text { al English journals } \\
\text { (22,442 words); } \\
20 \text { English RAs } \\
\text { in international } \\
\text { English journals } \\
\text { ( } 37,243 \text { words) }\end{array}$ & $\begin{array}{l}\text { RAs written by Chi- } \\
\text { nese scientist writers } \\
\text { who studied and } \\
\text { worked at Chinese } \\
\text { universities after } \\
\text { being conferred } \mathrm{PhD} \\
\text { degree. }\end{array}$ \\
\hline
\end{tabular}

\section{Results and discussion}

It is our purpose to highlight the most relevant findings of our review of previous work focused on the study of self-reference cross-culturally in RAs as well as to discuss some salient methodological aspects of such studies. However, given the 
different size of the corpora on which they are based, the varied number of variables taken into account in their compilation, the divergent realizations considered and the different presentation of results, it is difficult, and beyond our scope, to draw systematic comparisons across all those studies.

\subsection{Studies of RAs from Southern Europe}

Quite a lot of studies on the use of personal reference in academic discourse in English and in Spanish have been undertaken. Even though Spanish could be considered an international language, since it is used as an L1 in numerous countries and by many speakers worldwide, national quality systems and policies favouring English-medium impact publications make it more and more pressing for Spanish academics to draft their papers in English and seek international publication in this language. Intercultural research has been carried out on the use of self-mentions as stance markers in RAs in the two L1s and contexts of publication: in English by Anglophones addressing an international readership and in Spanish by Spaniards addressing a more local readership (Mur-Dueñas 2007; Sheldon 2009; Williams 2010). Mur-Dueñas (2007) reported significant differences in the use of first person plural references and self-citations in RAs in the field of Business Management; Anglo-American authors writing in highimpact journals make a more frequent use of these stance markers to establish their authorial persona - especially when describing the procedure followed, stating their hypothesis and indicating their limitations or strengths - than scholars in the same discipline publishing their RAs in Spanish in more local journals. These results contribute to creating a different writer-reader relationship in each context.

Similar conclusions were reached by Sheldon (2009) in her contrastive study of personal pronouns in Applied Linguistics RAs in English and in Spanish. She found less significant differences in the extent of use of self-references in one and the other corpus, but reported relevant divergences in their particular functions. In English texts the reflexive $I$, through which authors introduce narrative and explicatory forms, is more common than in the Spanish texts, in which the $I$ as guide or navigator, used to organize the text and to create a path for the reader, is more common; such uses may entail a less authoritative role. Overall, "English writers reveal professional or personal information about themselves with firstperson autobiographical narratives" (Sheldon 2009: 261).

Williams (2010) looked into the same features in biomedicine RAs and found no significant differences in their frequency of use in RAs written in English and in Spanish; in some RAs personal references were even more frequent in the Spanish than in English texts. In this study relevant divergences are also noted in the functions that self-mentions commonly perform in each group of texts. In the English texts their main function is the "expression of non-standard methods and of personal choices and decisions. The authors assume responsibility for their actions, and so leave readers free to decide whether to accept or reject the validity of the results" (Williams 2010: 222). The tendency for scientific authors to use 
we for unique procedural choices was already noted by Tarone et al. (1981: 128) in their analysis of two Astrophysics papers. This strategic use of the first person will draw the reader's attention, signaling that something discoursally significant is taking place, something which does not occur in the Spanish texts.

Some English-Spanish contrastive research has focused not just on the use of self-mentions in RAs in either language but on the use made of such features in English texts by Spanish scholars (Carciu 2009; Lorés-Sanz 2011a, 2011b; Martínez 2005; Pérez-Llantada 2010). Martínez (2005) found that exclusive first person pronouns in RAs in Biology were less commonly used by non-native Spanish speakers of English than by native English writers, especially in the Results and Discussion sections. Lorés-Sanz (2011a, 2011b) also found notable differences in an English and a Spanish English sub-corpus in the field of Business Management. She also looked at L1 Spanish texts and concluded that the RAs in English written by Spanish scholars occupy a mid-position in terms of frequency of selfmentions, as if reaching a compromise between what is expected from them in the international community and what they commonly do in Spanish. However, such differences are not found in Carciu's (2009) English and Spanish English sub-corpora in the field of Biomedicine, in line with Williams' (2010) results on the same discipline. She finds similar uses of we pronouns in terms of their discourse roles in each RA section in the two sub-corpora. As Carciu (2009) states, her results may point towards the internationalization - and progressive standardization - of academic discourse (Mauranen et al. 2010) at least in this particular discipline. In her view, they may also reflect the Spanish scholars following a "go native" trend in their L2 articles published in international English-medium RAs; that is, Spanish scholars may undertake an accommodation process to the rhetorical conventions prevailing in international RAs written by Anglophone academics. In her account of text- and participant-oriented metadiscourse in biomedicine English, Spanish and Spanish English RAs, Pérez-Llantada (2010) notes a difference in the use of self-mentions regarding the function "Introducing the topic" in the first section of the RA between the English and the Spanish RAs. Whereas in the Spanish texts authors opt for impersonal metadiscourse units, such as inanimate subject constructions, in the English texts written by Spanish authors a personal metadiscourse expression is preferred, namely, exclusive we references serving self-promotional goals: "Spanish scholars publishing internationally tend to adopt similar rhetorical strategies to those used by Anglophone writers" (Pérez-Llantada 2010: 62), which is in accordance with Carciu's (2009) results.

Several of these contrastive studies also point out particular features in the use of self-mentions in Spanish and Spanish English RAs such as the use of we in single authored RAs, the magisterial plural (Mur-Dueñas 2007; Lorés-Sanz 2011a, 2011b; Sheldon 2009). This has also been found in RAs in other Romance languages, namely Italian (Molino 2010) and Portuguese (Bennett 2010).

Some studies have also compared the use of self-reference in English and Italian RAs. Molino's (2010) results of her contrastive analysis of the use of personal pronouns and passive constructions in Applied Linguistics RAs in English 
and Italian are similar to those comparing English and Spanish writing conventions in the Humanities and Social Sciences discussed above. English writers tend to project a stronger persona including more self-references. Molino (2010: 95) concludes that "Anglo-American writers overall favour the use of exclusive first person pronouns as an interpersonal strategy, Italian writers prefer a more detached interpersonal style by opting predominantly for passive and si constructions". However, diverging results are found in the rhetoric of English and Italian historians when it comes to stating the purpose of their research (Bondi 2007). Whereas in her English corpus the purpose is commonly attributed to the text itself, the Italian corpus shows a preference for discourse participants, which entails a greater inclusion of self-mentions. Bondi (2007: 81) concludes that American historians would be emphasizing their role as impersonal narrators, whereas Italian historians respond to "a disciplinary tradition that attributes great value to forms of 'document archeology' and to an academic tradition of writing that values personal interpretation much above reader legibility".

\subsection{Studies of RAs from Western, Eastern and Northern Europe}

While the use of personal pronouns is frequently analysed contrasting English with some other language, there are also studies that look at several languages, thus offering a more diverse cross-cultural perspective. Vassileva (1998) investigated self-mentions in English, German, French, Russian and Bulgarian in a corpus of Linguistics RAs. The quantitative results of her analysis offer striking differences of personal pronoun distribution in the five languages. English authors clearly dominate in their use of personal pronouns, while in Bulgarian and German self-mention is roughly twice less frequent, with Russian researchers employing personal pronouns even to a lesser extent. The lowest number of personal pronouns was observed in French scientific texts.

An even more interesting distribution is between the $I$ and we perspectives. Even though all articles were single authored, it is the we perspective which is totally predominant in Russian ${ }^{2}$ and Bulgarian. As one of the possible explanations for this pattern, Vassileva refers to Clyne's (1993) concept of collective vs individualistic cultural orientations. Vassileva suggests that Russian and Bulgarian cultures follow the collective approach, which could be the result of communist ideology influence, as "[i]t is a well known fact that this ideology aims at suppressing the individual in favour of the community" (Vassileva 1998: 181). English, German and French employ both $I$ and we, however, $I$ is more frequent than we only in English. The clearly dominating $I$ perspective in English is explained by Vassileva as the authors' wish to emphasize their role in scientific texts.

Vassileva's findings for the German language have been confirmed in a more recent study by Sanderson (2008), who looked at personal pronoun usage in German, British English and American English. Sanderson's corpus is carefully balanced with regard to various important criteria: gender, age and academic status of the authors. The range of disciplines has been selected to represent the humani- 
ties as widely as possible and includes Philosophy, History, Folklore, English/ German Literary Studies and English/German Linguistics. Sanderson's results show that the $I$ perspective has been adopted by the English native speakers nearly 2.5 times more frequently than by their German colleagues, thus confirming the tendency for the "culturally specific I-taboo" (Sanderson 2008: 71) in German texts. The first person plural is also statistically more frequent in English texts. Interestingly, Sanderson found that there is no significant difference in the first person pronoun usage across the two varieties of English.

Discipline-related findings of Sanderson's study also point towards interesting trends of cross-cultural differences. The history texts are the only ones in the corpus that display a higher number of personal pronouns in the German subcorpus than in the English one. Sanderson suggests it could be due to the fact that German history texts contained more male writers of high academic status. However, the results are in line with Bondi's (2007) findings for Italian and English history texts and might be suggestive of history discourse following slightly different epistemological traditions in English. Overall, Sanderson concludes that "the 'Itaboo' appears to hold for German academic writing in the humanities" (2008: 89).

The 'I-taboo' seems to be even more clearly manifested in the French academic discourse as is shown by Vassileva (1998). Similar results are reported by Fløttum et al. (2006) who state that French researchers use the lowest number of personal pronouns in comparison with English and Norwegian scholars and generally seem to avoid the $I$ perspective. These results are consistent with previous studies on French academic discourse which introduced the French cultural maxim "le moi haïssable" ('the I to be hated') emphasized in French academic tradition (see Fløttum et al. 2006: 81, 113, 264).

Similar preferences in personal pronoun usage have been found in the study of Dutch and Lithuanian academic discourse in the humanities and social sciences by Šinkūnienè and Van Olmen (2012). Their study found that non-third person forms very rarely combine with modal verbs of necessity in Dutch and Lithuanian academic discourse in comparison to personal pronouns used in combination with must in English. While English researchers try to involve the reader and emphasize their own involvement using inclusive we must and reader-oriented you must, Dutch and Lithuanian scientists typically distance themselves from their claims of necessity employing impersonal constructions and passive voice. The trend of Lithuanian researchers to avoid first person pronouns has been also reported by Šinkūnienè (2010) who analyzed a corpus of RAs in Linguistics and Medicine in English and Lithuanian. The results of the analysis show that English researchers employ personal pronouns much more frequently than Lithuanian researchers in both disciplines. Just like in Russian, Bulgarian, German, French and, Spanish the $I$ perspective was avoided in single authored articles in Lithuanian academic discourse, and in those cases when researchers chose to use a personal pronoun, it was we in an overwhelming number of cases. The study also looked at the functions typically performed by personal pronouns in both 
disciplines and both languages. Researchers in Linguistics seem to be more homogeneous in that respect, frequently employing first person pronouns to engage the audience in argumentation. In medical discourse, explanation of the research procedure was clearly dominating in English, but less prominent in Lithuanian, where researchers would use personal pronouns to explain the procedure as well as to report results with a similar frequency.

Shaw's (2003) analysis of Danish academic discourse shows similar trends to those reported in the studies already reviewed and discussed. He explores personal pronoun usage in Applied Economics as a part of a larger study of evaluative language comparing articles written by Danes in Danish, the same scholars in English and English researchers (i.e. researchers based in institutions in Britain, the USA or New Zealand) writing in English. The results of the study show that Danish scholars writing in Danish barely used personal pronouns while English scholars employed them quite extensively. Danish English occupied a middle position. Shaw states that apparently "the Danes are merely staying with the general rhetorical convention and there is no need for an explanation other than that their national science supports a different norm of impersonality" (Shaw 2003: 354-355). This result is in line with the use Spanish scholars make of this feature in a closely related discipline, that of Business Management, in English (LorésSanz 2011a, 2011b).

Rhetorical and stylistic norms regarding the authors' projection in the text by means of self-reference appear to be different in another Northern European academic writing tradition. Unlike Danish scholars writing their RAs in Danish or in English, Norwegian scholars seem to be more prone to express their stance overtly through personal pronouns. Fløttum et al.'s (2006) study of first person subjects in RAs in linguistics, economics and medicine written in Norwegian, French and English shows that Norwegian scholars' use of first person subjects is more similar to English researchers than that of French. However, when looking at the particular roles writers take depending on the functions first person singular pronouns perform, Fløttum et al. (2006: 92) conclude that "Norwegians are more writers than arguers and that English authors argue more explicitly than Norwegian ones". These observations once again confirm the individualistic approach that English scholars seem to manifest while constructing their academic texts across most disciplines studied in previous research.

\subsection{Studies of RAs from Southern and Eastern Asia}

Like studies in European languages, Persian academic discourse analyses compare self-reference use, primarily as part of metadiscourse, in local contexts with the English academic discourse trends in international settings seeking to identify culture specific patterns and norms. Abdi's (2009) study of metadiscourse in soft and hard science fields (see Table 1 for specific disciplines) in English and Persian RAs shows that the biggest difference is in their use of self-mentions, with the latter being more impersonal than the former. 
The general trend to avoid personal pronouns in Persian academic discourse has also been confirmed in subsequent studies of personal pronouns as part of metadiscoursal devices by Zarei and Mansoori (2011), Fatemi and Mirshojaee (2012) and Taki and Jafarpour (2012). Taki and Jafarpour (2012) notice that Persian writers tend not to use self-mentions and when they do, they more readily employ the word 'the researcher' to refer to themselves, while Fatemi and Mirshojaee's advice for Iranian writers is to "move away from positivist impersonalized text performance towards more socialist presentation of knowledge claims and writers' stance and voice" (Fatemi and Mirshojaee 2012: 261).

Dawang (2006) looks at personal pronoun use in the English language medium RAs written by Chinese researchers and published in international English journals and local Chinese English journals. Those two groups of articles are compared with English articles written by native speakers and published in international English journals in material sciences. The distribution of personal pronoun usage among those varieties of English does not seem to present a pattern different from most of the reviewed studies. Anglophone scholars use personal pronouns most, whereas Chinese researchers writing for local publications employ the fewest number of those author stance devices. Chinese authors writing for international publications occupy a middle position. In terms of pragmatic functions, stating results or claim appeared to be predominant among the personal pronoun functions employed by Chinese researchers writing for local English language journals. Dawang (2006) finds this interesting in the context of non-native English discourse which is thought to be less prone to adopt high-risk discoursal strategies.

\section{Final remarks}

Our review of the cross-cultural research carried out on the use of self-mentions in different language and culture contexts leads us to conclude that overall there seems to be a general tendency in the use of this stancetaking feature in RAs across languages and local contexts of publication across Europe and Asia, setting Anglophone scholars apart in their more common inclusion of self-references in their texts addressed to an international audience. In general terms, it seems that the projection of the scholars' persona in RAs by means of personal subject pronouns does not seem to be the norm in the lingua-cultural local contexts analysed by previous research, and self-reference is to a certain extent avoided.

The use of self-reference seems to be favoured to a much larger extent in English RAs published internationally, the English scholars having a much more overt presence in their texts. Past research has systematically highlighted that the use of this rhetorical feature is both a matter of disciplinary and linguistic culture-specific conventions and preferences, and of context of publication. The use of this stancetaking marker may be subject to whether scholars want to enter 'packed houses' or 'intimate gatherings' (Burgess 2002). That is, in order to claim 
a space in the 'packed' competitive sphere of international publication, authors need to make a strong authorial presence in their texts making clear their own contribution to the field, which may lead them to a more frequent use of self-references and to use them for more risk taking discourse functions as the reviewed studies have highlighted.

As indicated in the previous section, in the existing literature not only differences in the frequency of use of self-mentions in RAs written in English and in other languages have been reported but also, and perhaps more significantly, in the functions performed by those self-mentions. When self-references are used in RAs in different languages in local contexts, these tend to be mainly related to the structure and organization of the article, whereas in RAs in English they tend to be used to a greater extent, depending on the discipline, to describe procedures, to highlight main or significant findings and to argue particular issues. The image or role of the authors as projected by their use of this rhetorical feature is, therefore, stronger.

Nevertheless, the existing literature also points at significant differences in the extent of inclusion of self-mentions in RAs in one or the other language and context of publication across disciplinary fields. More striking differences are found in the extent of use as well as their rhetorical functions performed by first person subject pronouns in humanities and social sciences than in hard sciences, and particularly in biomedical sciences. Most of the cross-cultural studies of personal pronouns reviewed in this article are within the soft sciences field with medicine and biomedicine being virtually the only representatives of hard sciences. Even though cross-disciplinary comparison was not the major focus of our study, there do seem to be significant disciplinary differences. An explanation for this trend is offered by Hyland (2005b) who claims that researchers in soft science domains rely more on interpretative results and therefore have to employ more of the reader involving devices than scholars in the hard sciences. Also, academic knowledge as published in social sciences and humanities seems to be more culturally-bound than in pure sciences, in which textual and discursive norms and conventions tend to be more homogenous in terms of their textual and structural features (Duszak 1997).

It is also significant to point out how in a large number of languages and local contexts of publication, (e.g. Spanish, French, Russian, Bulgarian, German, Lithuanian) the $I$ perspective seems to be avoided to a great extent, and when authors include a personal reference, this tends to be plural (even when the RA is single-authored), in a possible attempt to sound less personal. As suggested by Loffler-Laurian (1980 cited in Fløttum et al. 2006: 106) for the French academic discourse, this could be the result of the author's wish to appear to voice not his or her ideas but those of a larger group. Perhaps this textual practice can be extended to other cultural contexts as well. Anglo-American authors publishing their RAs in international journals, however, do use the pronouns $I$ in single-authored RAs. This may be related to collective vs. individualistic cultures (Clyne 1987, 1993). Members of smaller academic communities communicating through their L1 locally may be considered collective, favouring a less personal discourse, whereas members of bigger academic communities communicating internationally in 
English may be considered rather individualistic, influenced by Anglo-American more personal discoursal choices and driven by the need to emphasize own achievements and contributions to find a space for publication in a competitive international context.

Relevant findings have also been reported in the literature in the extent to which authors from different L1s adjust to the differing conventions regarding the use of self-mentions when they write and publish the results of their research in English-medium international journals. In many cases their rhetorical options occupy a mid-position between the conventions prevailing in their local publication contexts in their L1 and those prevailing in the international English-medium publication context. Again, disciplinary communities play a significant role and the rhetorical options are more homogeneous in fields such as medicine and biomedicine - in which authors adjust to a greater extent to the use commonly made of self-reference in international RAs in English - than in other fields such as linguistics or business management.

The research reviewed has important implications for EAP and the study of English as a lingua franca in academic contexts (Mauranen 2012). From the research reviewed in this article, it can be concluded that some degree of divergence, at least in the use of the particular rhetorical feature under study, that of author projection by means of self-reference, does not hinder international publication. Nevertheless, because authors do not fully retain the prevailing conventions in their L1 contexts, it seems that some degree of accommodation to the expected uses is called for, but also some discourse hybridity (Mauranen et al. 2010) appears to be acceptable at least in certain disciplinary domains. In order to explore this issue in more depth, further analyses would be needed which focus on the writing process, not only the writing product, of RAs by users of English as a lingua franca for publication processes, paying attention to the resources and strategies they use as well as to the role played by EAP formal instruction and/or 'literacy brokers' (Lillis and Curry 2010).

The research reviewed shows that there is a wide array of identity expression options in RA writing which are dependent on the small and big cultures to which scholars belong, which especially novice writers should be made aware of. These options contribute to projecting different images of the writer, to taking on different roles in the recounts of their research, as well as to creating differing writerreader relationships.

Despite the relevance of past research, our review has revealed important methodological divergences across studies and issues which may need to be considered by future research. Previous work is based on comparable corpora following diverse criteria and variables. RAs in English have been generally selected on the basis of their "nativeness", mainly taking into account the authors' name, and especially, their affiliation. However, no differentiation has been made across different Englishes or Anglophone authors, with the exception of Sanderson's (2008) work. English "native" speakers are grouped together when it may be the case that British, North American or Australian scholars use different rhetorical 
options as regards self-representation in RAs.

Also, in a moment when English is used for research publication and dissemination by scholars of varied lingua-cultural backgrounds in international publications, ELF corpora of RAs may need to be compiled and analysis of self-reference and other rhetorical conventions made across different similects (Mauranen 2012). Given the current widespread use of ELF in academic settings, diachronic studies may also be undertaken to explore the extent to which English academic discourse as used in particular academic genres evolves. Furthermore, research reporting on the use made of this and other stancetaking features should draw attention to the role of the prescriptive materials and/or the normative use of certain language features which tend to be included in EAP materials. EAP materials, in turn, need to be based on the actual rhetorical practices of scholars writing in English as shown by the literature.

Other variables which may influence the choice of particular rhetorical options and the subsequent identity expression reflected in the text, and which have received quite scarce attention in the literature, are seniority or academic status, and gender. Sanderson's (2008) study shows that these variables are significant and reveal important trends towards the use of personal pronouns in academic discourse. From a methodological point of view it is important to take into account those factors while compiling the corpus, as according to Sanderson (2008: 77) failure to control for "communicative situation, gender, age and relevant social factors, or control their data only for one or two variables, will not provide reliable results". These individual features may have to be taken into account in future studies of stance features in academic writing in different languages and especially in English as a lingua franca. As shown by our study, previous analyses tend to be based on ad hoc corpora which differ greatly in terms of size. Regardless of the different number of words the corpora consist of, findings seem to be consistent in reporting a more frequent use of self-references in RAs written in English, addressed to an international readership than in RAs written in other language for local audiences.

Reviews of the existing research on academic discourse are quite scarce but necessary as they help to see the broader context of how epistemological practices of different science areas evolve, what similarities or differences there are in distinct cultures and disciplines, which academic discourse features seem to be universal and which ones culture or discipline specific. Further studies should be carried out which review the previous work on interpersonal, rhetorical and discursive features in academic writing which may have been published not only in leading journals, as is the case of this article, but also locally in different languages and different sites of publication, which will help make that research visible and scholars from other language contexts be aware of that research. Thus, this review of self-reference in European and Asian academic discourse is only a tip of the iceberg in reviewing the universality and specificity of academic discourse within the context of small and big cultures. 


\section{Notes}

1 The list of the studies under review may not be exhaustive as it was limited to the search the authors could undertake at their respective institutions. The search was also limited to the publications in languages that the authors could read.

2 Similar patterns of avoiding the use of personal pronouns in general and the $I$ perspective in particular has been reported in Russian and Ukrainian academic discourse by Yakhontova (2002, 2006) who analyzed conference abstracts in Applied Linguistics and Applied Mathematics.

\section{Acknowledgements}

The first author is indebted to the Spanish Ministry of Economy and Competitiveness for financing the project "English as a lingua franca across specialised discourses: a critical genre analysis of alternative spaces of linguistic and cultural production" (Project Reference FFI2012-37346), and to the Gobierno de Aragón and the Fondo Social Europeo for their support of the research group InterLAE (Interpersonalidad en el Lenguaje AcadémicoEscrito / Interpersonality in Written Academic Language) (H21). The second author wishes to thank the European Union Structural Funds project "Postdoctoral Fellowship Implementation in Lithuania", which funded research for this article.

\section{References}

Abdi, Reza (2009) "Projecting cultural identity through metadiscourse marking; A comparison of Persian and English research articles". Journal of English Language Teaching and Learning 52 (212), 1-15.

Ädel, Annelie (2006) Metadiscourse in L1 and L2. Amsterdam and Philadelphia: John Benjamins.

Atkinson, Dwight (2004) "Contrasting rhetorics/contrasting cultures: Why contrastive rhetoric needs a better conceptualization of culture". Journal of English for Academic Purposes 3, 277 289.

Bennett, Karen (2009) "English academic style manuals: A survey". Journal of English for Academic Purposes 3, 43-54.

Bennett, Karen (2010) “Academic discourse in Portugal: A whole different ballgame?" Journal of English for Academic Purposes 9, 21-32.

Bondi, Marina (2007) "Historical research articles in English and in Italian: A cross-cultural analysis of self-reference in openings". In: Bertuccelli Papi, Marcella, Gloria Cappelli and Silvia Masi (eds.) Lexical Complexity: Theoretical Assessment and Translation Perspectives. Pisa: PLUS, $65-84$.

Burgess, Sally (2002) "Packed houses and intimate gatherings: Audience and rhetorical structure". In: Flowerdew, John (ed.) Academic Discourse. London: Longman, 196-225.

Carciu, Oana (2009) "An intercultural study of first-person plural references in biomedical writing”. Ibérica 18, 71-92.

Cargill, Margaret and Sally Burgess (2008) "Introduction to the Special Issue: English for Research Publication Purposes". Journal of English for Academic Purposes 7 (2), 75-76.

Clyne, Michael (1987) "Cultural differences in the organization of academic texts". Journal of Pragmatics 11, 211-247. 
Clyne, Michael (1993) "Pragmatik, Textstruktur und kulturelle Werte. Eine interkulturelle Perspective". In: Schröder, Hartmut (ed.) Fachtextpragmatik. Tübingen: Gunter Narr Verlag, 3-18.

Connor, Ulla (1996) Contrastive Rhetoric: Cross-cultural Aspects of Second Language Writing. New York: Cambridge University Press.

Connor, Ulla (2004a) "Introduction". Journal of English for Academic Purposes 3 (4), 271-276.

Connor, Ulla (2004b) "Intercultural rhetoric research: Beyond texts". Journal of English for Academic Purposes 3 (4), 291-304.

Crismore, Avon, Raija Markkanen and Margaret S. Steffensen (1993) "Metadiscourse in persuasive writing". Written Communication 10 (1), 39-71.

Dahl, Trine (2004) "Textual metadiscourse in research articles: A marker of national culture or of academic discipline?” Journal of Pragmatics 36, 1807-1825.

Dawang, Huang (2006) "A tale of two English-language publication contexts for Chinese scientists -recontextualization in the coalesced Results and Discussion section”. In: Pérez-Llantada, Carmen, Ramón Plo Alastrué and Claus Peter Neumann (eds.) Actas de V Congreso Internacional AELFE / Proceedings of the 5th International AELFE Conference, 19-28.

Diani, Giuliana (2008) "Introductory 'it' patterns in English and Italian academic writing: A crossgeneric and cross-cultural analysis”. L'analisi Linguistica e Letteraria 16, 343-355.

Duszak, Anna (1997) "Cross-cultural academic communication: A discourse community view". In: Duszak, Anna (ed.) Culture and Styles of Academic Discourse. Berlin, New York: Mouton de Gruyter, 11-39.

Fatemi, Azar Hosseini and Seyyed Bagher Mirshojaee (2012) "Interactional metadiscourse in English and Persian research articles; A contrastive rhetoric study". The Iranian EFL Journal 8 (1), 246-268.

Fløttum, Kjersti, Trine Dahl \& Torodd Kinn (2006) Academic Voices-across Languages and Disciplines. Amsterdam, Philadelphia: John Benjamins.

Hyland, Ken (2001) "Humble servants of the discipline? Self-mention in research articles". English for Specific Purposes 20, 207-226.

Hyland, Ken (2002) "Authority and invisibility: Authorial identity in academic writing". Journal of Pragmatics 34, 1091-1112.

Hyland, Ken (2005a) Metadiscourse. Exploring Interaction in Writing. London: Continuum.

Hyland, Ken (2005b) "Stance and engagement: A model of interaction in academic discourse". Discourse Studies 7 (2), 173-192.

Kaplan, Robert B. (1966) "Cultural thought pattern in inter-cultural education". Language Learning XVI $(1,2), 1-20$.

Kaplan, Robert B. (1988) "Contrastive rhetoric and second language learning: Notes toward a theory of contrastive rhetoric". In: Purves, Alan C. (ed.) Writing across Languages and Cultures. Newbury Park: Sage Publications, 275-304.

Lafuente-Millán, Enrique, Rosa Lorés-Sanz, Pilar Mur-Dueñas and Ignacio Vázquez (2010) "Interpersonality in written academic discourse: Three analytical perspectives”. In: Lorés-Sanz, Rosa, Pilar Mur-Dueñas and Enrique Lafuente-Millán (eds.) Constructing Interpersonality: Multiple Perspectives on Written Academic Genres. Newcastle: Cambridge Scholars Publishing, 13-39.

Lillis, Theresa and Mary Jane Curry (2010) Academic Writing in a Global Context: The Politics and Practices of Publishing in English. London: Routledge.

Loi, Chek Kim and Moyra Sweetnam Evans (2010) "Cultural differences in the organization of research article introductions from the field of educational psychology: English and Chinese". Journal of Pragmatics 42, 2814-2825.

Lorés-Sanz, Rosa (2011a) "The construction of the author's voice in academic writing: The interplay of cultural and disciplinary factors". Text and Talk 31 (2), 173-193.

Lorés-Sanz, Rosa (2011b) "The study of authorial voice: Using a Spanish-English corpus to explore linguistic transference". Corpora 6 (1), 1-24.

Markkanen, Raija, Margaret S. Steffensen and Avon Crismore (1993) "Quantitative contrastive study of metadiscourse. Problems in design and analysis of data". Papers and Studies in Contrastive Linguistics 23, 137-151. 
Martín-Martín, Pedro and Sally Burgess (2004) "The rhetorical management of academic criticism in research article abstracts". Text 24 (2), 171-195.

Martínez, Iliana A. (2005) "Native and non-native writer's use of first person pronouns in the different sections of biology research articles in English". Journal of Second Language Writing 14 (3), 174-190.

Mauranen, Anna (1993) "Contrastive ESP rhetoric: metatext in Finnish-English economic texts". English for Specific Purposes 12, 3-22.

Mauranen, Anna (2012) Exploring ELF: Academic English Shaped by Non-native Speakers. Cambridge: Cambridge University Press.

Mauranen, Anna, Carmen Pérez-Llantada and John M. Swales (2010) "Academic Englishes: A standardized knowledge?" In: Kirkpatrick, Andy (ed.) The Routledge Handbook of World Englishes. London: Routledge, 634-652.

Molino, Alessandra (2010) "Personal and impersonal authorial references: A contrastive study of English and Italian linguistics research articles". Journal of English for Academic Purposes 9 (2), 86-101.

Mur-Dueñas, Pilar. (2007) “'I/we focus on...': A cross-cultural analysis of self-mentions in business management research articles". Journal of English for Academic Purposes 6 (2), 143-162.

Mur-Dueñas, Pilar. (2010) "Attitude markers in business management research articles: A crosscultural corpus-driven approach". International Journal of Applied Linguistics 19, 50-72.

Murillo, Silvia (2012) "The use of reformulation markers in Business Management research articles: An intercultural analysis". International Journal of Corpus Linguistics 17 (1), 64-90.

Nuyts, Jan (2001) "Subjectivity as an evidential dimension in epistemic modal expressions". Journal of Pragmatics 33, 383-400.

Pérez-Llantada, Carmen (2010) "The discourse functions of metadiscourse in published academic writing: issues of culture and language". Nordic Journal of English Studies 9(2), 41-68.

Sala, Michele (2008) "Argumentative styles as cultural identity traits in legal studies". Linguistica e Filologia 27, 93-113.

Sanderson, Tamsin (2008) "Interaction, identity and culture in academic writing: The case of German, British and American academics in the humanities". In: Ädel, Annelie and Randy Reppen (eds.) Corpora and Discourse: The Challenges of Different Settings. Amsterdam, Philadelphia: John Benjamins, 57-92.

Shaw, Philip (2003) "Evaluation and promotion across languages". Journal of English for Academic Purposes 2, 343-357.

Shaw, Philip and Irena Vassileva (2009) "Co-evolving academic rhetoric across culture; Britain, Bulgaria, Denmark, Germany in the 20th century". Journal of Pragmatics 41, 290-305.

Sheldon, Elena (2009) "From one $I$ to another: discursive construction of self-representation in English and Castilian Spanish research articles". English for Specific Purposes 28 (4), 251-265.

Sheldon, Elena (2011) "Rhetorical differences in RA introductions written by English L1 and L2 and Castilian Spanish L1 writers". Journal of English for Academic Purposes 10, 238-251.

Šinkūnienè, Jolanta (2010) “Autoriaus pozicijos raiška asmeniniais įvardžiais rašytiniame akademiniame diskurse". Filologija 15, 124-141.

Šinkūnienè, Jolanta and Daniel Van Olmen (2012) "Modal verbs of necessity in academic English, Dutch and Lithuanian: Epistemicity and/or evidentiality". Darbai ir Dienos 58, 153-181.

Taki, Saeed and Fatemeh Jafarpour (2012) "Engagement and stance in academic writing: A study of English and Persian research articles". Mediterranean Journal of Social Sciences 3(1), 157-168.

Tarone, Elaine, Sharon Dwyer, Susan Gillette and Vincent Icke (1981) "On the use of the passive in two astrophysics journal papers". The ESP Journal 1 (2), 123-140.

Vande Kopple, William J. (1985) "Some exploratory discourse on metadiscourse". College Composition and Communication 36 (1), 82-93.

Vande Kopple, William J. (2002) "Metadiscourse, discourse and issues in composition and rhetoric". In: Barton, Ellen and Gail Stygall (eds.) Discourse Studies in Composition. New Jersey: Hampton Press, 91-113. 
Vassileva, Irena (1998) "Who am I/who are we in academic writing? A contrastive analysis of authorial presence in English, German, French, Russian and Bulgarian". International Journal of Applied Linguistics 8 (2), 163-190.

Vold, Eva T. (2006) "Epistemic modality markers in research articles: a cross-linguistic and crossdisciplinary study". International Journal of Applied Linguistics 16 (1), 61-87.

Yakhontova, Tatyana (2002) “'Selling' or 'telling'? The issue of cultural variation in research genres”. In: Flowerdew, John (ed.) Academic Discourse. Harlow: Longman, 216-232.

Yakhontova, Tatyana (2006) "Cultural and disciplinary variation in academic discourse: The issue of influencing factors". Journal of English for Academic Purposes 5, 153-167.

Williams, Ian A. (2010) "Cultural differences in academic discourse: Evidence from first-person verb use in the methods sections of medical research articles". International Journal of Corpus Linguistics 15 (2), 214-240.

Zarei, Gholam and Sara Mansoori (2011) "A contrastive study on metadiscourse elements used in humanities vs. non humanities across Persian and English”. English Language Teaching 4 (1), $42-50$.

Pilar Mur Dueñas is a lecturer in the Department of English and German Studies at the Universidad de Zaragoza (Spain). Her research interests focus on written academic discourse, corpus studies, intercultural rhetoric and English as a lingua franca. She is a member of the InterLAE research group (Interpersonalidad en el Lenguaje Académico Escrito) (www.interlae.com).

Address: Pilar Mur-Dueñas, Departamento de Filología Inglesa y Alemana, Facultad de Educación, Universidad de Zaragoza, Campus Universitario, C/Pedro Cerbuna 12, 50009 Zaragoza, Spain. [e-mail:pmur@unizar.es]

JolANTA ŠINKŪNIENĖ works as Associate Professor at the Department of English Philology at Vilnius University (Lithuania). Her research interests primarily include genre analysis, cross-linguistic studies of academic discourse, corpus linguistics, modality and evidentiality.

Address: Jolanta Šinkūnienè, Department of English Philology, Faculty of Philology, Vilnius University, Universiteto str. 5, LT-01513 Vilnius, Lithuania. [e-mail: jolanta.sinkuniene@flf.vu.lt] 